\title{
An Assessment of Barriers to MSMEs' Adoption of CSA in Livestock Red Meat Value Chain, Kajiado County, Kenya
}

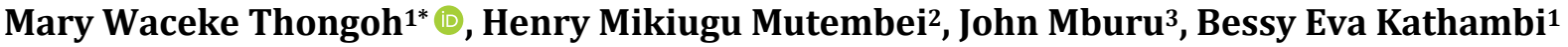 \\ ${ }^{1}$ Wangari Maathai Institute for Peace and Environmental Studies (WMI), University of Nairobi, Nairobi, Kenya \\ ${ }^{2}$ Department of Clinical Studies, University of Nairobi, Nairobi, Kenya \\ ${ }^{3}$ Department of Agricultural Economics, University of Nairobi, Nairobi, Kenya \\ Email: *muiaceke@gmail.com
}

How to cite this paper: Thongoh, M. W. Mutembei, H. M., Mburu, J., \& Kathambi, B. E. (2021). An Assessment of Barriers to MSMEs' Adoption of CSA in Livestock Red Meat Value Chain, Kajiado County, Kenya. American Journal of Climate Change, 10, 237-262.

https://doi.org/10.4236/ajcc.2021.103011

Received: June 9, 2021

Accepted: July 30, 2021

Published: August 2, 2021

Copyright $\odot 2021$ by author(s) and Scientific Research Publishing Inc. This work is licensed under the Creative Commons Attribution International License (CC BY 4.0).

http://creativecommons.org/licenses/by/4.0/

\begin{abstract}
Climate change poses great risks to poverty alleviation, food security and livelihoods sustainability in sub-Saharan Africa, declining crop yields and livestock productivity, especially in ASALs that suffer from fragile ecosystems characterized by frequent droughts and low rainfall. Climate-Smart Agriculture (CSA) objectives of improving productivity and incomes, adaptation, resilience to climate change and mitigation on GHGs emissions, are responses to these climate risks. CSA technologies, innovation and management practices (TIMPs) in general do exist, however they are concentrated in crop farming neglecting livestock production and especially in marginalized areas such as ASALs, which forms $85 \%$ of Kenyan land mass and is dominated by pastoral and nomadic livestock production. Most CSA practices are mainly at the production level and hardly extend to the entire value chain, and diffusion is slow due to several barriers. A mixed method approach was used to evaluate barriers to actors' adoption of CSA in the pastoral Livestock red meat value chain starting from input suppliers, producers, to consumers (pasture to plate). This study used six broad perspectives to examine the barriers: 1) Knowledge and institutional; 2) Market and financial; 3) Policy and incentives; 4) Networks and engagement platforms; 5) Cultural and social; 6) Physical infrastructure barriers. These barriers can be surmounted with concerted efforts from the government, development partners, pastoral communities, value chain actors and public private partnership among others. Efforts such as modernization of the pastoral red meat value chains, integration of MSMEs into the livestock systems, access to affordable financing, availability of context based, affordable CSA TIMPs,
\end{abstract}


incentives, policies and institutional support, which currently remains inadequate. Institutional barriers like lack of capacity, coupled with knowledge and behavioral barriers hinder adoption. Financial institutions and cooperative societies can be enablers, however, their reluctance to invest in the sector is a barrier too.

\section{Keywords}

Barriers, Climate-Smart Livestock, CSA TIMPs, Enablers, Incentives, Policies, Red Meat Value Chain

\section{Introduction}

Climate change poses new challenges to the fight against poverty and sustainability of agrarian livelihoods in sub-Saharan Africa through declining crop yields and livestock productivity caused by rainfall variability, rising temperatures, and increased pest/disease incidences (Grossi et al., 2019; Jordaan et al., 2014; Torquebiau et al., 2018). Increasing climate variability and extremes, affecting both crop and livestock systems, are indicated as one of the causes leading to the recent rise in global hunger, malnutrition, and severe food crises (Atela et al., 2018). The livestock sector is one of the major components of agriculture in Kenya and according to the ASDS 2010-2020, (Agricultural Sector Development Strategy), the livestock sector contributes $7 \%$ of the national GDP and $17 \%$ of agricultural GDP, and accounts for $50 \%$ of the agricultural labor force.

Kenya has launched ASTGS 2019-2029, (Agricultural Sector Transformation and Growth Strategy), towards agricultural transformation and 100\% Food Security in Kenya. ASTGS acknowledges that Kenyan economy has made impressive progress in areas like innovation and entrepreneurship, private sector enterprise, infrastructure, public service delivery and human capabilities but agriculture continues to be the foundation of Kenyan economic development and creation of equitable and sustainable growth for Kenyan people. ASTGS has three anchors among them; reduce the number of food-insecure Kenyans in ASAL regions while reducing the cost of food and improving nutrition and protect households against environmental and fiscal shocks. Improved agricultural productivity will also create more jobs, increase food supply and lower food prices, making food accessible and affordable (World Bank, 2019).

There are about 9 million poor livestock farmers in Kenya, which is approximately $28 \%$ of Kenya's rural population (World Bank, 2019). Kajiado County forms part of Kenya's major meat production region with beef value chain predominantly made up of cattle extensively reared on communally owned rangelands (Sourcebook, 2013; Alarcon et al., 2017; Ministry of Agriculture et al., 2018). Livestock production for red meat in Kenya can be divided into three main systems: 1) Pastoral production system (informal): responsible for $80 \%$ - 
90\% of red meat production in Kenya; 2) Ranching production system (formal): responsible for about $2 \%-3 \%$ of total production, principally for the high-value market; 3) Highland's production system (formal): produces the remainder (Bergevoet \& Van Engelen, 2014).

Agricultural production is becoming more relevant to climate change management strategies (Aggarwal et al., 2018; Khatri-Chhetri et al., 2019) from both mitigation and adaptation strategies as both agriculture and livestock production contributes almost one-quarter of the global human-induced GHG (Green House Gases) emissions and hence the need to mitigate through reduction of GHG emissions (FAO, 2003; Mwongera et al., 2019; Stein \& Barron, 2017; Tankha et al., 2020). At the national level, the Kenya Climate-Change Act, 2016 envisions "a climate resilient and low carbon growth sustainable agriculture that ensures food security and contributes to the national development goals."

There is minimal research and study on Climate change impacts on livestock systems and corresponding value chains (Godde et al., 2021) but indications are that Livestock sector is and will continue to suffer significant loss of productivity due to climate related reduction in forage and forage quality, water scarcity and increased livestock diseases, hence impacting the entire livestock value chain livelihoods and sustainability. In ASALs (Arid and Semi-Arid Lands), following a drought period it takes years for herd size to recover, affecting livelihoods, and in absence of financial resources to proactively re-stock through animal purchases, it takes decades (Thornton et al., 2019), pointing to the need for climate risk instruments such as emergency funds, grants, loans, animal and drought insurance and government supported policies on drought compensation scheme.

CSA (Climate-Smart Agriculture) advocates for coordinated actions among different actors in the value chain towards climate-resilient pathways through; building evidence-based research, increasing local and institutional effectiveness, fostering coherence between climate and agricultural policies and linking climate and agricultural financing. Even though CSA has the ability to provide adaptation and mitigation benefits, it's still not clear what type of transformation in policy frameworks, institutions and funding is necessary to aid adoption (Tankha et al., 2020). Appreciating the variables and dynamics which affect the diffusion of CSA and CSA TIMPs (Technology, Innovation and Management Practices), is an important factor in determining which CSA initiatives can successfully be integrated into livestock systems. Understanding and applying system and value chain thinking to food security and nutrition is important in order to get to the root cause of systems success or failure regarding climate change variability, impacts and resilience on food security (Birch, 2018). CSA TIMPs that sustainably increase productivity, support farmers' adaptation to climate change, and reduce levels of greenhouse gases, in general, do exist, however, their diffusion is slow and limited (Descheemaeker et al., 2016; Tankha et al., 2020). And where they exist, it's on crop farming, and mainly addressing 
producer level and not permeating the entire value chain (Pantano \& Di Pietro, 2012). ASALs Livestock value chains consist of input suppliers, producers, traders, middlemen, transporters, processors, distributors, retailers and consumers.

Addressing barriers and challenges to CSA adoption require consultations with all relevant stakeholders to advise suitable interventions and policy options (Descheemaeker et al., 2016; Khatri-Chhetri et al., 2019). The role of MSMEs (Micro, Small and Medium Enterprises) in scaling CSA adoption is considered due to their ability in driving local development, integrate women and other marginalized groups, innovate, have greater adaptability and flexibility which can be important drivers in building community resilience, poverty reduction, social adaptation (Atela et al., 2018). This study evaluates the barriers that reduce the effectiveness of climate adaptation strategies such as CSA, along the livestock red meat chains as represented in Figure 1 below.

The practice of livestock production, in Kajiado has been pastoralism that is dependent on migrating large herds of cattle, sheep and goats (shoats) into open grasslands (World Bank, 2019). Middle men, connect farmers to traders who act as aggregators buying animals from farmers even though some farmers chose to also act as traders buying from others and adding onto their own herd and transporting to the live animal markets. Along major livestock routes, cattle and shoats are trekked by farmers or hired youth or trucked by road from pastoral areas to primary and secondary markets such as Bisil and Kiserian, and then to terminal markets in Nairobi (Alarcon et al., 2017) by hired transporters. All along the chains, there are opportunities to integrate CSA practices however there are barriers that hinder adoption, especially capacity and investment (Descheemaeker et al., 2016; Khatri-Chhetri et al., 2019).

\subsection{Theoretical Underpinning}

Two theories underpin the conceptual model of this study; the transactional theory and the diffusion theory. In the transactional theory, it is argued that the adoption of a given concept or technology is hindered by the knowledge and attitude of the individuals adopting it; the perceived benefit of their actions (Khalifa \& Ning Shen, 2008; Kim \& Crowston, 2011; Pantano \& Di Pietro, 2012).

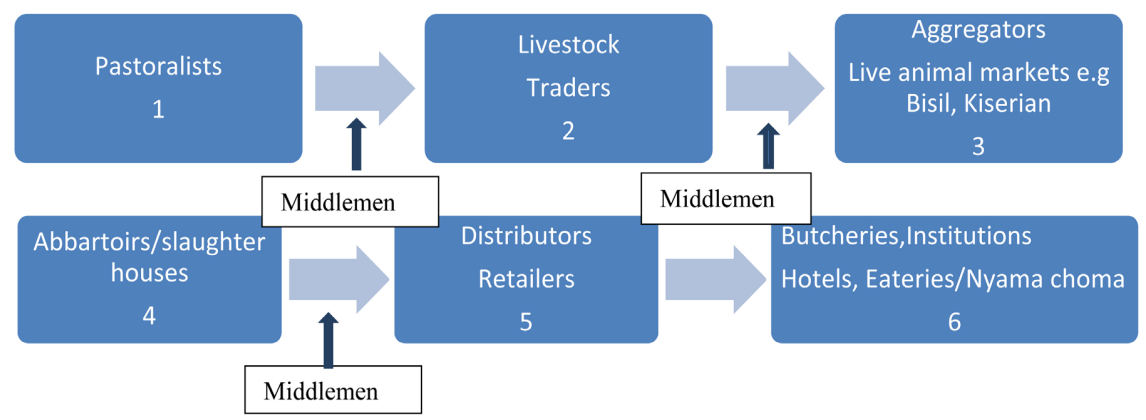

Figure 1. Pastoral livestock red meat value chains. 
Moreover, if the benefit is not imminent, e.g. in case of CSA where the benefits tend to be realized in the long term, there is a lack of buy-in (Kim \& Crowston, 2011). In a social network actors exist in a networked environment where they exchange goods, value and information. The second theory used, is the diffusion/adoption theory of innovations developed by E. M Rodgers (Scott \& Mcguire, 2017; Dearing \& Cox, 2018). The decision on whether an individual will adopt a particular practice and or technology and the time frame involved with that decision has been a long source of research as it affects various disciplines (Dearing, 2009). The adoption of a given technology is therefore influenced by the characteristics of a given population (Dearing, 2009). The population is therefore defined into categories, there are the innovators who want to be the first to move with the technology and always interested in new ideas, more risk takers, ready and capable and there is just very little to be done for them to adopt a technology, practice or concept (Zhang et al., 2015). The second group is early adopters who need a few convincing evidences, they represent opinion leaders and therefore enjoy leadership roles, embrace change opportunities (Smith et al., 2018). Third, are the early majority, people who are not leaders but are capable of adopting new technologies and practices before the average person. They typically need to see some evidence that the practice or concept works and they will be willing to adopt, evidence of success stories may be the best strategies to be used in appealing to these category (Zhang et al., 2015). The late majority are the fourth group, they represent people who are skeptical, those who cannot take risks and can only risk adoption after a majority of people have tried it, then finally are the last group called laggards who basically lag behind others, they are very conservative and bound by tradition, they resist change and looking into the study area in which livestock is basically for prestige, this category is the group who may not be able to embrace climate-smart livestock practices, they therefore need to be taken out of their fear and will only adopt when they have no other choice but to do so (Mukanyandwi et al., 2019; Smith et al., 2018; Zhang et al., 2015).

\subsection{The BEAR Model for Enabling Adoption of Sustainability Practices}

BEAR Model in Figure 2, shows that to enable adoption of sustainability practice, one has to first assess the benefits of a practice and barriers that would hinder adoption. Then identify possible factors that can create an enabling environment/ecosystem to remove the barriers and drive adoption of the practice, coupled with tracking the realization of benefits as adoption gradually takes place and in turn the benefits realized act as evidence to slow adopters and skeptics and reinforcing further adoption, until the sustainable practices become fully adopted and integrated by all actors in their daily practices and, in this case, the red meat value chain become climate-smart (climateresilient). 


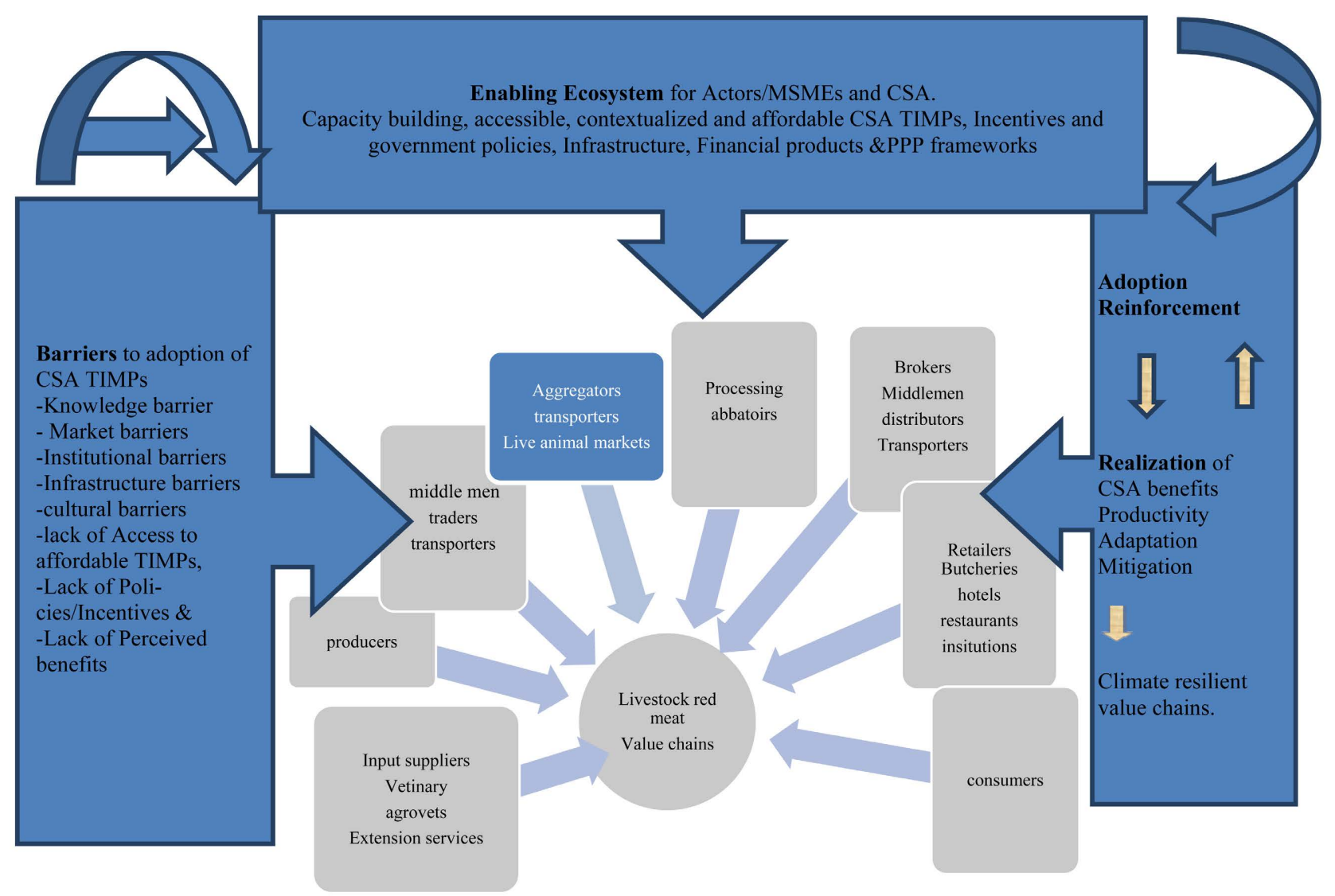

Figure 2. The BEAR model: Enabling adoption of sustainability practices by Thongoh.

\section{Research Methodology}

\subsection{Study Area}

This study was conducted in four out of the six sub counties of Kajiado County, Kenya (Figure 3). When conducting the field work, considerations of the culture of the inhabitants were taken into account. Kajiado County is situated between Longitudes $36^{\circ} 5^{\prime}$ and $37^{\circ} 5^{\prime}$ East and between Latitudes $10^{\circ} 0^{\prime}$ and $30^{\circ} 0^{\prime}$ South. The county covers an area of $21,900.9$ square kilometres $\left(\mathrm{Km}^{2}\right)$. The current Kajiado CIPD 2018-2022, (County Integrated Development Plan) indicates pastoralism as a major economic activity in the county with major stocks being cattle, sheep and goats. Livestock trade and products such as milk, beef and chevon, hides and skins form the main part of household incomes (CIPD 2018-2022).

\subsection{Research Design}

The study adopted both quantitative and qualitative study designs. A crosssectional survey was done (Ishtiaq, 2019) and a questionnaire was used to carry out in depth interviews of actors from inputs suppliers, processors to consumers (pasture to plate). Besides, personal observation during site visits to livestock keepers, livestock traders, market outlets and processors was carried out including key informant interviews. 


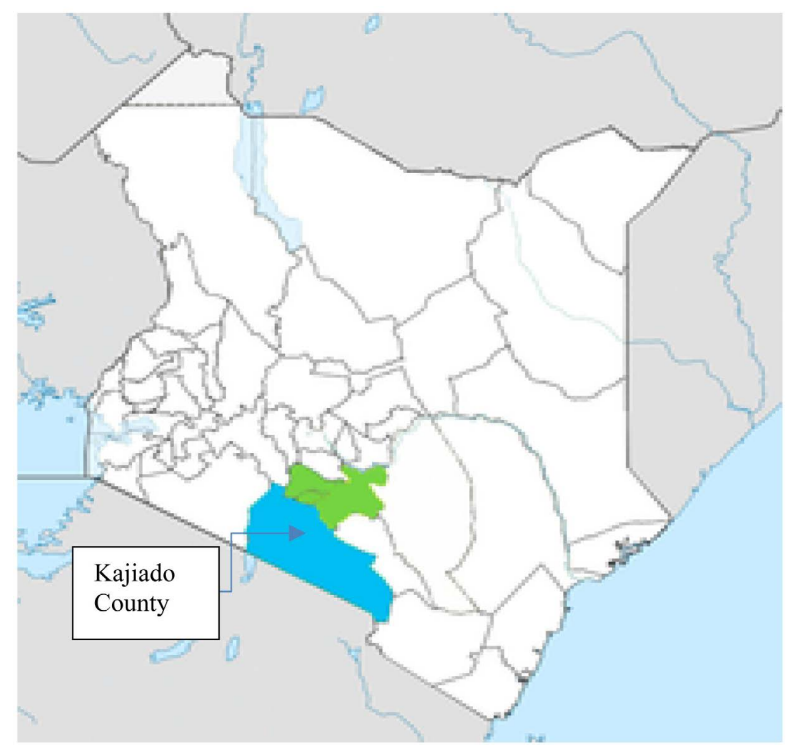

Figure 3. The map of the study areas-map of Kenya showing Kajiado County.

\subsection{Data Collection and Analysis}

Both quantitative and qualitative data were collected. The data and information captured processes of production, distribution and marketing. Key informants interviews (KII) included input suppliers, producers, traders, middlemen, processors, and distributors/retailers, consumer and stakeholders in the extended and enabling value chain (extension officers, bankers, insurance agencies, and microcredits, central and county government, government agencies, development partners and research institutions and universities). Following (Matsui et al., 2020) and (Mutisya \& Barker 2011), a sample size of 459 respondents were sampled across the value chain. Context and thematic analysis were used for analyzing the qualitative data while the quantitative data was analyzed with the aid of Statistical Package for Social Sciences (SPSS) and reported in tables, frequencies, charts and graphs. Statistical inferences were also made from regression, chi-square and differences observed in various actors using the $95 \%$ confidence interval $(P \leq 0.05)$.

\section{Results}

This study categorized and examined the barriers to adoption from 6 perspectives namely; 1) Knowledge and institutional barriers; 2) Market and financial barriers; 3) Policy and incentives barriers; 4) Networks and engagement platforms barriers; 5) Cultural and social barriers; 6) Physical infrastructure barriers. The results presented in this study, provide an overview of the barriers that the livestock red meat value chain actors (MSMEs) experience in adoption of CSA TIMPs.

\subsection{Knowledge and Institutional Barriers}

In Table 1, we examine knowledge and institutional capacity of the value chains 
Table 1. Knowledge-based barriers to implementing CSA practices.

\begin{tabular}{cc}
\hline Knowledge Infrastructure & Percent \\
\hline Lack of awareness/information on climate smart livestock & $28 \%$ \\
Lack of education, training, empowerment, communication & $28 \%$ \\
$\begin{array}{c}\text { Confusing climate smart livestock with corporate social } \\
\text { responsibility (CSR) and other sustainability initiatives. }\end{array}$ & $27 \%$ \\
Total & $18 \%$ \\
\hline
\end{tabular}

actors, this revealed that most actors lacked awareness or information regarding climate-smart agriculture (28\%), in addition to lack of extension or advisory services as shown by $28 \%$ of the actors. Another $27 \%$ of the actors expressed that the lack of capacity building was a hindrance towards adoption of CSA technologies while $18 \%$ cited a lack of understanding on the difference between CSA, other sustainability practices and CSR (corporate social responsibility), these barriers are echoed by other studies (Gledhill \& Herweijer, 2012; Smith et al., 2018; Abegunde et al., 2020). There is the need for minimum definition, interventions and innovations of what would consist of sustainable practices in a changing climate and how CSA fits into this, to guide design of context based TIMPS and practices contextualized to the ASALs livestock red meat value chain and the unique needs of the pastoral and nomadic communities.

Cross-tabulation results indicated that actors had varied awareness of the various sustainability and climate change concepts with producer, middlemen/ aggregators, distributors/retailers and consumers being more aware on reducing poverty and building resilience, input suppliers being aware of increased productivity and building resilience and processors, being relatively knowledgeable on the five constructs (climate-smart animal/livestock agriculture, increasing productivity, building resilience, livelihoods/livelihoods protection and reducing poverty). Knowledge by itself is not sufficient to drive adoption if the MSMEs do not have capacity to innovate and invest in new ideas and technologies.

\subsection{Market and Financial Barriers}

Figure 4 shows barriers associated with market infrastructure and financial barriers, which reveals that the majority of the actors lacked access to inputs and technologies on CSA (17\%) and financial support services that would enhance adoption (16\%). In addition, $15 \%$ of the actors expressed that return on investments informed decisions to adopt the CSA while $14 \%$ felt that CSA technologies were costly. The main marketing channel indicated by producers is the live animal markets (primary and secondary markets which are dominated by middlemen and traders). Nearly three quarters of pastoralists do not have prior access to market information (Otieno et al., 2012). Consumers 
I do not see any benefit/value in adopting climate smart practices

Lack of customer support to implement climate smart practices I have other pressing priorities/it is not a priority Lack of markets

Do you believe customers would be willing to pay more if you tell them that you practice CSA TIMS?

Climate smart practices and technologies are very expensive

Return on investments informs decision to adopt CSA TIMPs

Lack of financial support services/credit/loans/insurance/grants to implement climate smart practices.

Lack of access to inputs, and technology

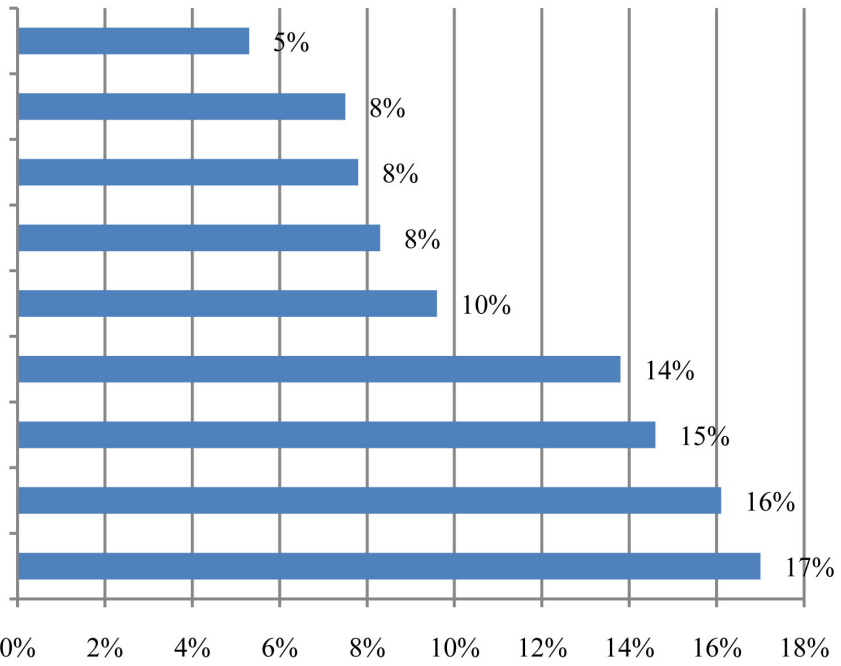

Figure 4. Market and financial barriers.

believed that information asymmetry allows middle men to take advantage of farmers, giving them lower prices for their animals yet meat in Kenya is a high price food whose economic benefit does not trickle back to farmers hence affecting their incomes and ability to invest in modern technologies and sustainable practices that would need financial resources. For abattoirs/slaughterhouses, they indicated that the key inputs into their processes are water, labor and electricity, these three form the highest overheads, eroding their already thin margins and hinder their ability to invest in sustainable practices or modernize the slaughterhouses.

The perceived high cost of CSA TIMPs, prevalence of middlemen combined with lower prices to producers and slim profit margins for value adding activities along the chain, were among the key issues identified as hindering adoption and investment into CSA. This is not surprising because nearly 800 million of the livestock keepers are rural poor, surviving on less than 2 USD a day (Gledhill \& Herweijer, 2012) and especially for ASALs rural poor households.

Table 2 shows that among the sustainable practices adopted by producers to mitigate against climate change ranged between $8 \%$ and $12 \%$ and only one financial product/practice i.e., livestock insurance/emergency fund, was utilized at a minimal level of $12 \%$.

Figure 5 shows the technologies and practices employed by the value chain actors beyond production level and only two were financial products i.e., an emergency fund (13\%), insuring businesses against weather effects (13\%). Among retailers and abattoirs only retailers had cold storage facilities and just a few of them reported that they did not need storage facilities (37.8\%) and that cold storage equipment was expensive $(21.8 \%)$ hence indicating a financial barrier. Non-importance of cold storage facilities was also supported by $14.5 \%$ who reported that all meat is sold before end of day and $12.6 \%$ of consumers buy enough for consumption for a day due to high cost of meat. The veterinary 


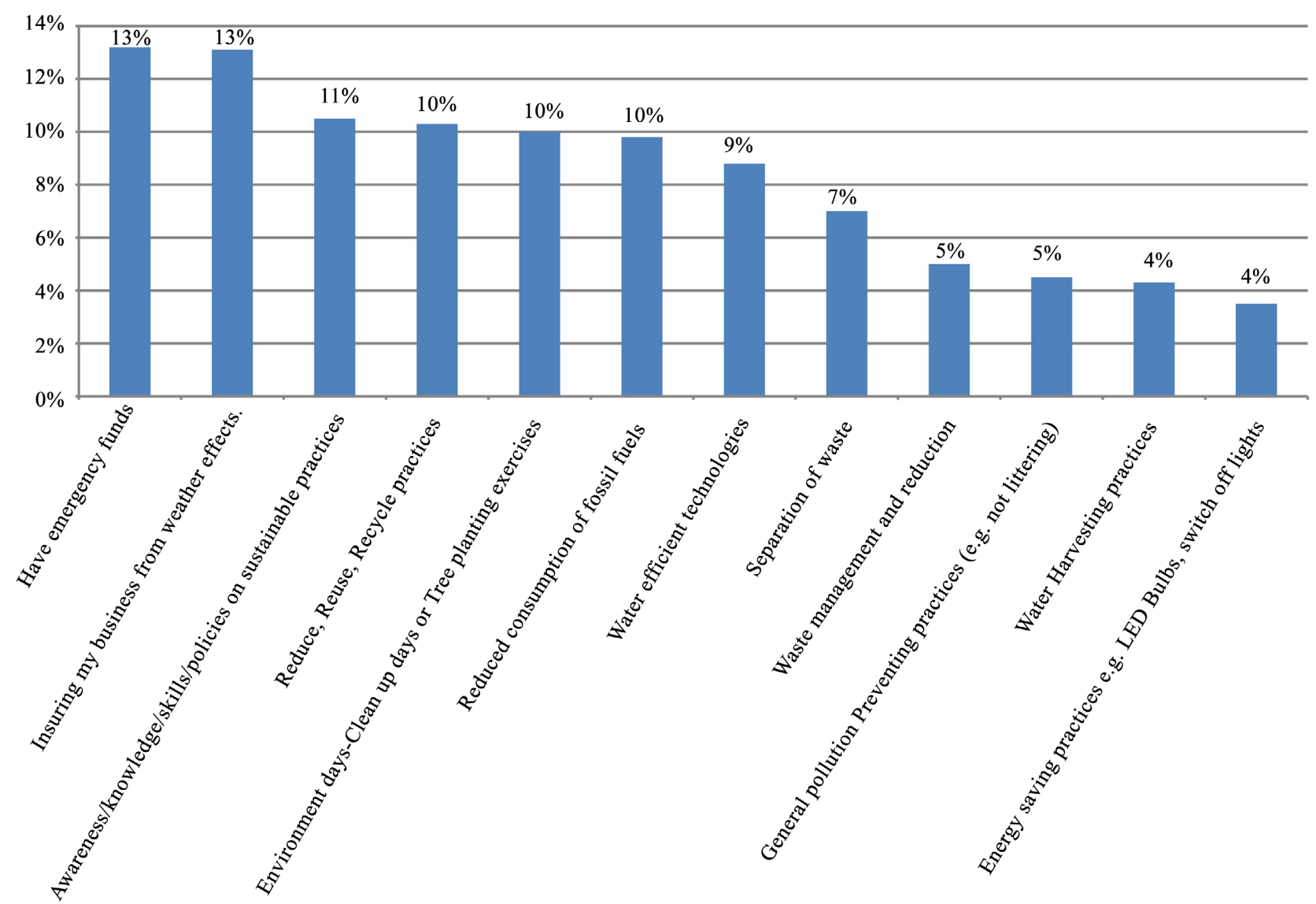

Figure 5. Climate smart technologies in use by the value chain actors.

Table 2. Sustainable practices, technologies or innovations used by actors.

\begin{tabular}{cc}
\hline Parameter & $\begin{array}{c}\text { Practiced } \\
\text { by (\%) }\end{array}$ \\
\hline Livestock insurance/emergency fund & $12 \pm 0.6^{\mathrm{a}}$ \\
Water harvesting for livestock & $12 \pm 0.6^{\mathrm{a}}$ \\
Crop and livestock mix & $11 \pm 0.55^{\mathrm{a}}$ \\
Adaptive breeds/animal breeding/appropriate breeds/animal genetic resources & $11 \pm 0.55^{\mathrm{a}}$ \\
Manure and composting & $10 \pm 0.5^{\mathrm{a}}$ \\
Keeping a variety of livestock & $10 \pm 0.5^{\mathrm{a}}$ \\
Reduce/reuse/recycling e.g., Biogas & $9 \pm 0.45^{\mathrm{a}}$ \\
Weather warning/agro-weather systems & $9 \pm 0.45^{\mathrm{a}}$ \\
Grassland management and restoration/pasture management & $8 \pm 0.4^{\mathrm{a}}$ \\
Better feeds and feed supplements & $8 \pm 0.4^{\mathrm{a}}$ \\
\hline
\end{tabular}

Confidence Interval $(\mathrm{CI})=95 \%$.

officer in one of the abattoirs indicated that lack of storage facilities meant abattoir operated daily based on the daily consumers' demand and orders placed by traders and aggregators, this further implied the abattoirs were not optimally 
utilizing their $100 \%$ capacity each day hence driving up operating costs. If they had storage facilities, they could operate optimally at $100 \%$ on certain fixed days of the week where they would slaughter the entire day and store supply for distribution for the rest of the week, reducing operating costs due to economies of scale. The low use of storage facilities due to cost is further compounded by cultural social norms that dictate consumer behavior, whereby consumers especially pastoralists prefer freshly slaughtered meat because it's said to taste better compared to stored meat and for this reason $90 \%$ buy their meat from local butcheries compared to supermarket, because the supermarket meat is stored in cold fridges for many days and hence lacks taste.

\subsection{Policy and Regulatory Barriers}

Figure 6 presents the results on barriers associated with policy barriers. Majority of the value chain actors (25\%) cited lack of government support, incentives, subsidies, governance systems and programs while $24 \%$ cited lack of government laws, rules and regulations that demand adoption of CSA and CSA TIMPs and $22 \%$ cited lack of standards for CSA adoption. Policy and regulatory barriers account for $71 \%$ of the barriers.

\subsection{Networks and Engagement Platforms Barriers}

Other barriers cited were related to the interactions of the actors within and among core value chain and extended and enabling value chains, through networks, collaborations and partnerships. From the results, half of the actors felt that there were no associations in place to exchange information, ideas, and collectively advocate and push for the implementation of sustainable practices such as CSA. While the other half cited lack of specific frameworks for collective

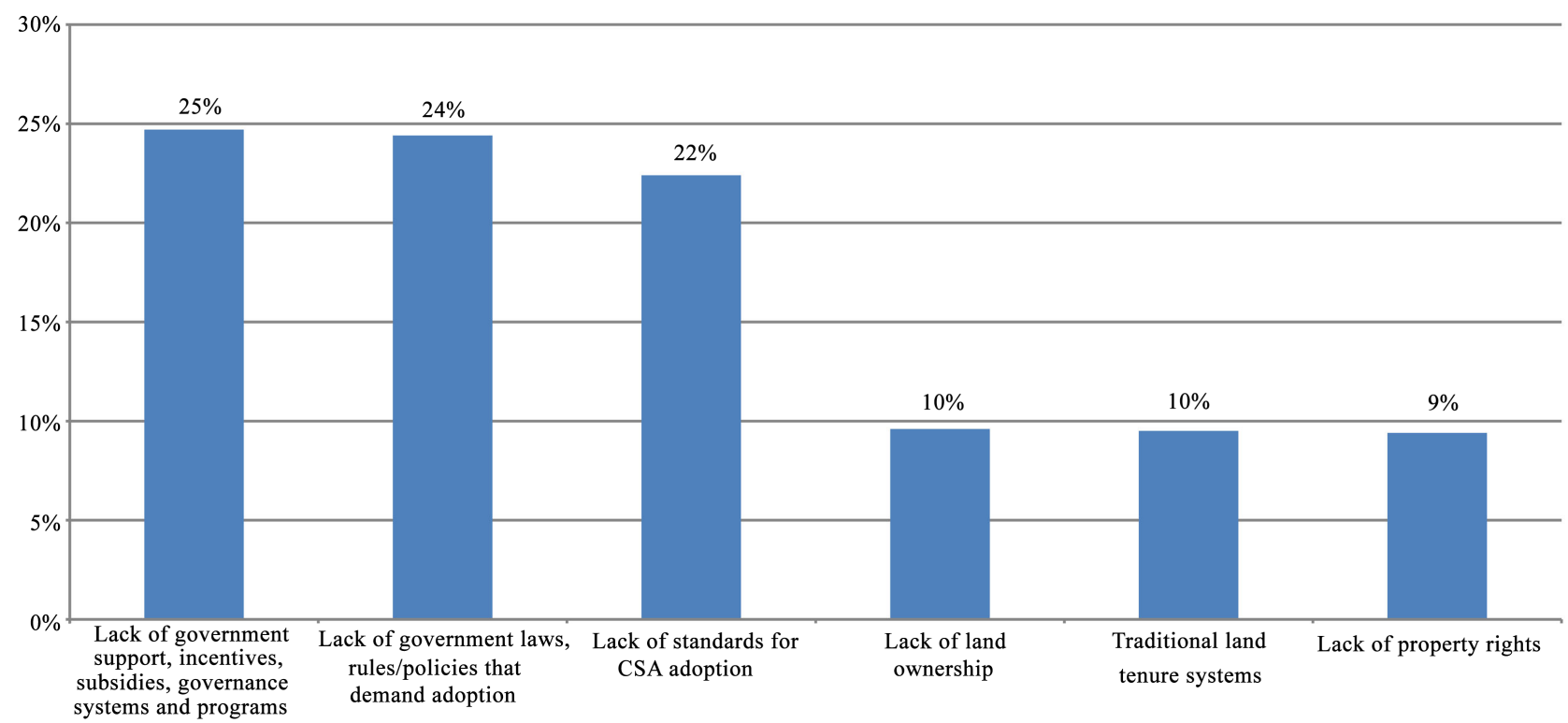

Figure 6. Policy and institutional barriers. 
actions such as cooperatives, partners, including opportunities for Public-Private Partnership (PPP) within ASALs livestock value chain. Actors pointed that lack of such multi-stakeholders' platforms that would mobilize and leverage numbers and resources among the ASALs red meat value chain actors was a hindrance towards adoption of practices such as the CSA and modernization of the value chains (Figure 7). For instance, knowledge and awareness level of the concept of climate change and CSA among the actors show that collectively there is a fair level of knowledge but separately there are knowledge gaps among the actors which can be closed if the actors had platforms of interactions where they can share knowledge and exchange information. Input suppliers such as private sector agro vets, Ngong veterinary farm and county veterinary doctors, attached to each abattoir, indicated that livestock production in ASALs faces unique challenges due to the transhumance nature of pastoralism, predisposing it to conflicts from land grazing rights and water resources, which is further complicated by the blockage of migratory routes due to acquisition of land along migratory routes for housing due to ballooning urban population, and indiscriminate use of livestock drugs and antibiotics coupled with counterfeit drugs leading to drug resistance and exacerbation of livestock diseases, all these challenges can possibly be resolved if actors could network, organize and come up with sustainable solutions.

Concerning sources of information on climate change-related concepts results (Figure 8), indicate that the commonly used sources of information were workshops, training courses and media, these three accounting for $68.4 \%$ and extension and agriculture officers $(18.3 \%)$ and only $5 \%$ get their information from business association/(CBOs) community based organizations or informal

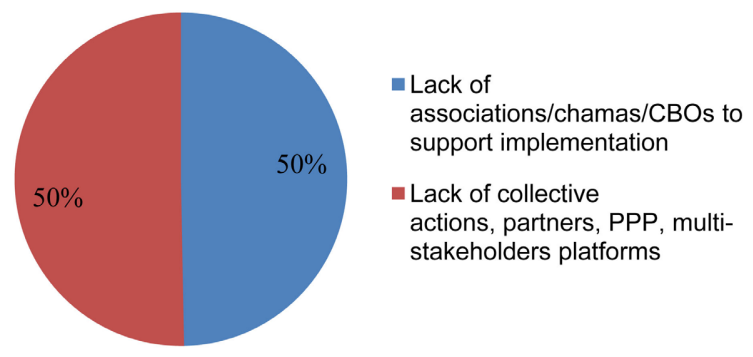

Figure 7. Networks and interaction platforms barriers.

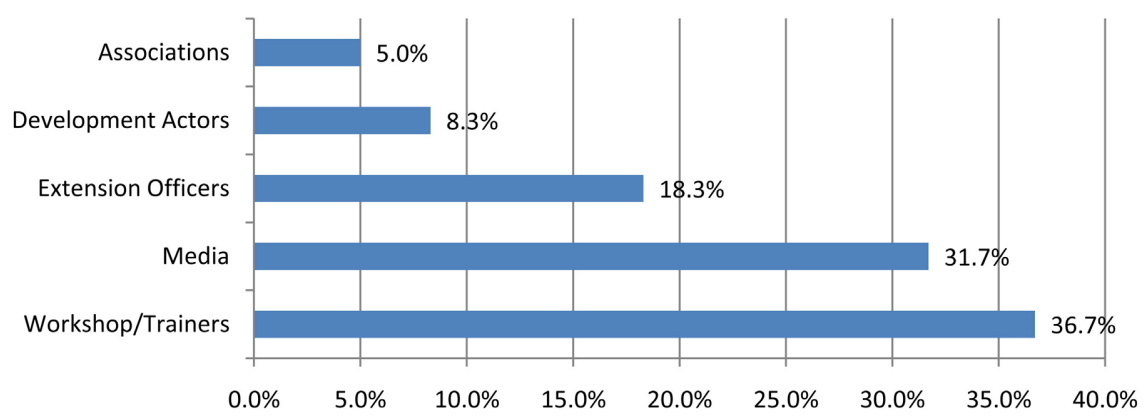

Figure 8. Sources of information on climate change-related concepts. 
groups known as chamas. This implies that value chain actors do not have an avenue to network and exchange relevant information in order to strengthen their participation, and engagement with the value chain while enabling adoption of sustainable practices such as CSA.

This study found only two community-based organizations, and whose main role was to manage the live animal markets in Kiserian and Bisil Markets. Their roles are limited to managing the market days, providing security, cleaning the market, levying fees from livestock traders and solving disputes. There was no evidence of organized awareness, knowledge and capacity building efforts for livestock chain actors, mainly farmers, traders, middlemen and transporters who patronized the markets. The СBO manager at Bisil Market indicated that the main information exchanged is informal market banter and mainly on issues such as price, weather, animal breeds and livestock diseases and possible drugs to use. Knowledge and awareness can be built through experience, formal and informal training, exposure and social cues like peer-to-peer influence and exchange of information among the actors in the value chains if platforms were available.

\subsection{Cultural Perceptions and Social Barriers}

With regards to barriers related to the perception and attitudes of the actors towards CSA practices, results in Table 3 indicate that majority of the actors (44\%) thought that CSA TIMPs are a preserve for commercial, large farms and businesses while $25 \%$ expressed that their pastoral and nomadic traditions and religious beliefs discouraged the adoption of CSA TIMPs. $21 \%$ of the actors just did not believe that CSA practices are good. The Kajiado County government and financial institutions cited the prevailing view that CSA TIMPs are for commercial, large farms and businesses as a key aspect hindering the integration of CSA TIMPs by actors within the pastoral red meat value chains and hence the need to raise awareness and customize CSA to microenterprises who dominate the pastoral value chains. Further, traditional customs, norms and lack of trust in regards to new practices and technologies was cited as a barrier to adoption of CSA, because adoption can only result from social norms and behavior that promotes environmental sustainability (UNEP, 2010).

However, at the local level, the study found that incrementally small scale producers and value chain actors had adopted some sustainable practices through

Table 3. Soft Institutional related barriers.

\begin{tabular}{cc}
\hline Soft institutional-social cultural dimension, customs, values, attitudes, gender & Percent \\
\hline CSA TIMPs are for commercial, large farms and businesses & $44 \%$ \\
Traditional customs/norms or religious beliefs discourage CSA TIMPS & $25 \%$ \\
I do not trust or believe CSA Practices are good. & $21 \%$ \\
Because I am male or female & $10 \%$ \\
Total & $100 \%$ \\
\hline
\end{tabular}


trial and error of 'no regret' options, i.e. alternatives that are viable and beneficial such as mixed crop farming, ASALs adaptable livestock breeds, feeds supplements, indigenous livestock treatments and drugs, water pans, solar panels and energy-saving bulb to increase climate resilience though there is still need for scale and major transformation of the livestock value chains if tangible benefits and sustainability are to be realized, since there are limits to what benefits can be realized through incremental adaptation especially for the poor ASALs livestock value chain actors.

\subsection{Physical Infrastructure Barriers}

The physical infrastructure for red meat value chains mainly consists of roads, availability of power, and connection to power lines, water and sewer lines especially for abattoirs, built areas/physical market for live animals, processing structures and equipment, i.e., slaughterhouses and abattoirs, trucks and infrastructure for transportation of the animals to the live animal markets and slaughterhouses, transportation of slaughtered carcasses and meat by distributors and retailers.

Table 4 shows the barriers associated with physical infrastructure, $50 \%$ of the actors expressed a lack of physical infrastructures e.g. good roads, those do not flood or get washed away during the rainy season, as a hindrance towards adoption of sustainable practices such as CSA while the other $50 \%$ cited lack of power or energy sources or where present, the power was too costly.

In ASALS Climate change also has impacts on human productivity and animal health, traders indicated that during the many long days of trekking the animals many kilometers on rural roads to live primary animal markets, and due to extreme heat there is significant animal body weight loss due to dehydration, affecting productivity, meat quality and price. The producers preferred easily accessible markets and abattoirs that eliminate the long treks, especially as youth who are used to trekking the animals migrate to urban areas leaving the aged to trek the animals.

\section{Discussions}

This study found that even though Climate-smart agriculture (CSA) is one response to the challenges faced by the agriculture sector, the adoption and diffusion of CSA technological innovations and novel management practices is slow. This is due to several barriers, the first being due to lack of awareness and knowledge on both the process and tools of CSA among the wide demographic

Table 4. Physical infrastructure associated barriers.

\begin{tabular}{ccc}
\hline Physical infrastructure & N & Percent \\
\hline Lack of access to transport/roads/facilities/some form of assets & 252 & $50 \%$ \\
Lack of power/source of energy or energy costs are high & 249 & $50 \%$ \\
Total & 501 & $100 \%$ \\
\hline
\end{tabular}


of value chain actors that is mainly dominated by youth and male actors. The actors did not have full knowledge and understanding of the climate change concept in relation to the livestock production and value chains, even though knowledge was unevenly distributed with input suppliers such as agrovets, and processors having higher levels of knowledge (Thorlakson \& Neufeldt, 2012; Abegunde et al., 2020). Therefore understanding how the social systems that include level of education, age and gender affects awareness and sustainability mindset can be critical in addressing the barriers to application, adoption and scaling of CSA TIMPs among the actors (Etwire et al., 2017; Mutisya \& Barker, 2011; Mwongera et al., 2019). Sustainability mindset needs to start with awareness and knowledge, in order for CSA to be adopted across the entire value chain beyond production, into marketing and processing sectors of the livestock (Otieno et al., 2012; Said et al., 2016).

Sustainability of climate-smart initiatives is highly dependent upon knowledge, attitudes and practices (KAPs) of the actors on the same (Fielding \& Hornsey, 2016). Adoption and sustainability of climate-smart initiatives are dependent on knowledge, attitudes and practices of the actors (Said et al., 2016), and these attributes influence the behaviour of the actors involved in the way they interphase and interact with government and regulating institutions (Maina, 2020; Raciti et al., 2011). There is an urgent need to enhance awareness and enforcement of sustainability values and mindsets among citizens and in particular, CSA within the livestock value chains, beyond the county government cleanup initiatives and NEMA environmental protection enforcement campaigns currently in place. Institutional theory approach should be considered, because it outlines deeper and more adaptable aspects of social structure, whereby values are built by social and cultural institutions that establish schemes, rules, norms, and routines, which then become accepted as authoritative guidelines for social behavior and mainstreamed into policy and regulations (Scott, 2004), leading to buy-in hence better and faster adoption.

Typically, Individuals require evidence and or demonstrations that the technology to be adopted works before they make a decision to embrace it (Dearing \& Cox, 2018). Since many actors along the chain have not adopted CSA TIMPs, there is limited evidence to convince other actors to adopt and equally after adoption CSA TIMPS require some time to start showing some returns on investment, hence discouraging adoption. In social network theory actors exist in a networked environment where they exchange goods, values and information (Barro \& Sala-I-Martin, 1992; Fang, 2009; Thorlakson \& Neufeldt, 2012) hence KAPs can be built through informal exchange of ideas and experiences, formal training and social cues as actors intersect. The study also found that there were limited platforms or organised networking opportunities for actors to exchange information that can positively impact adoption and strengthen their participation in the value chains. Successful adoption of a given technology depends on teamwork and going by the diffusion and adoption theory (Baker, 2005; Abegunde et al., 2020), it is only when the late adopters, as they interact with their 
peers who are early adopters, see the realized benefits of CSA as demonstrated by the early adopters and innovators that the laggards could be willing to support (Zhang et al., 2015; Smith et al., 2018); hence the need to create possible platforms where actors can interact, exchange ideas, model desired behaviors and practices and influence their peers. Personal attitude (Dai et al., 2018) and psychological factors such as environmental identity and values (Fielding \& Hornsey, 2016), are also important to adoption of sustainability practices such as CSA. In livestock value chain, for instance, the actors would embrace climate-smart practices that ensure maximum yields and profitability, if they saw evidence of the same among their peers (Ali et al., 2014; Ericsson \& Lindberg, 2018; Williamson et al., 2010).

The study also found institutional capacity barriers where the MSMEs felt they were not large enough to adopt the CSA TIMPs or practices. Large in terms of revenue, staff capacity and market reach to adopt CSA TIMPS, one respondent indicated, "you need to have made enough money to adopt some of these technologies." The low level of knowledge on CSA as a concept and CSA TIMPs also affects attitudes, This agrees with a similar study on institutional related barriers (Baker, 2005) where it was found that inadequate institutional capacity and commitment, uncertainty about the technology and its reliability as the leading institutional barriers (Mukherjee \& Sarkar, 2018; Smith et al., 2018). The organization theory on innovation activities can also shed further light on this. It has long been posited that constrains in capacity limit an organization's ability to innovate, and that slack resources, (whether human, financial or technical), are key elements for organization's ability to make investments in innovation. Lack or limited slack resources inhibits experimentation which is even more necessary, for this resource constrained MSMEs, to fuel their innovation and growth. Experimentation is often considered as an unaffordable luxury or waste by limited by MSMEs, especially because of uncertainty of success or return on investment. Moreover, tightly wound organizations experience higher levels of internal conflict, which is also unfavorable to innovation (Tankha et al., 2020).

This study found out that there are many barriers to scaling up successful CSA pilots and issues related to an enabling environment, among them being financing and equity barriers (Linnér \& Wibeck, 2020; Vermeulen et al., 2012). MSMEs in the livestock value chain are not willing to take loans to enable them adopt the available CSA TIMPs due to lack of financial security and the high interests by the lenders are prohibitive. Additionally the financial institutions were also reluctant to venture into the livestock sector citing unproductivity, climate stress risks, lack of security and poor loans repayment as a big risk in lending to the rural poor (Gledhill \& Herweijer, 2012; Thorlakson \& Neufeldt, 2012; Descheemaeker et al., 2016). The banks also indicated that there is a lack of available range of TIMPs for actors to choose from making what is available limited, not compatible to the needs of the actors or expensive, and when the actors look for loans, they do not have enough knowledge about available technologies or the banks' policies and offerings do not have any products tailored for the CSA 
TIMPs. Among financial institution interviewed the only possible CSA Technology loan product that was available from two banks in Kajiado was the solar panel loan, which even the large slaughter houses such as those found in Kitengela and Kiserian sub county said were quite expensive. One slaughter house had taken a loan to put up a biomass plant which eventually ran into operating and maintenance challenges, could not produce sufficient energy to mitigate the slaughter houses' high energy costs and eventually the project was abandoned without having paid back the loan. To effectively understand climate change and design appropriate TIMPs and related financial products in relations to pastoral red meat value chains, awareness and knowledge by both the core value chains actors and financial institution is an essential element in the response to climate change and related climate risks (Tasquier et al., 2014). Financial Institutions and cooperatives play a major role as enablers in the value chain, with their financial assistance, they enhance access and adoption of the technologies (Descheemaeker et al., 2016; Gledhill \& Herweijer, 2012; Thorlakson \& Neufeldt, 2012). Innovative mechanism for de-risking pastoral livestock value chains and enhancing financial institutions' (FIs) focus to lend to MSMEs in the red met value chain is important. There is also the need for technical assistance to FIs and MSMEs to ensure that adequate products and services are developed to address climate resilience and adoption of CSA TIMPs and MSMEs have adequate institutional capacity to experiment, innovate, adopt and scale their use of CSA TIMPs.

That notwithstanding, MSMEs in the sector have reported that apart from lack of sufficient financial resources, other competing priorities for the same resources hinder them from adopting CSA. Rural poor households in ASALs have different competing needs to allocate the limited financial resources and face substantial trade-offs when using resources, and value chain actors are not able to assume higher risks when reinvesting limited capital (Devaux et al., 2018) and the fact that consumers will be unwilling to pay more for end products if the cost of adopting CSA was included into the costing of the final product. The study found that actors consider return on investment as key criteria when adopting a practice and would willingly embrace climate-smart practices that ensure maximum yields and profitability (Ali et al., 2014; Ericsson \& Lindberg, 2018; Williamson et al., 2010). Combining livestock keeping with crop farming can act as a form of income diversification, savings or collateral, and risk reduction for the poor rural populations (Descheemaeker et al., 2016) and further aid adoption by providing needed slack resources for CSA technologies.

Cost factors, as seen from the study, have an influence on how actors adopt climate-smart practices. $15 \%$ of the value chain actors cited return on investments being the basis of the decision to adopt CSA TIMPs. Moreover, according to the transactional theory of technology adoption, individuals will be willing to adopt a particular concept or theory if there is a benefit they will gain from it (Dearing, 2009; Khalifa \& Ning Shen, 2008) otherwise they will not adopt.

The costs of technological innovations are prohibitive, especially early on in 
the diffusion process due to difficulties in initial commercialization efforts. The expense of establishing production facilities, as technology developers transform themselves into technology producers, often means that profits are hard to obtain and increase the costs of the innovative product or service (Cullen et al., 2014; Faber \& Hoppe, 2013; Nkonya et al., 2015); these can be expressed as "early adopter costs" (Gonzalez, 2005), and impact both technology users as well as technology producers, so there is need to subsidize both the input supplier and the user, in this case, CSA technology producers in order to make CSA TIMPs affordable to the value chain actors and for the actors to consider purchasing. According to diffusion theory, if the benefit of practice is not imminent, e.g. in case of CSA where the benefits tend to be realized in the long term, the actors are slow to embrace the technology (Kim \& Crowston, 2011).

The consumers also indicated the need for better meat quality and safety especially following recent public awareness on meat safety in Kenya and government enforcement of the same; hence this presents an opportunity to not only comply but to develop and green the red meat value chains, through investments and adoption of sustainable practices such as CSA TIMPs.

The study also confirmed the need for systems approach to assessment and design of CSA solutions, enabling policies and incentives, taking into account the entire value chain since currently the majority of TIMPs, polices and incentives such as those needed to enable adoption of sustainable practices e.g. CSA TIMPs, address only certain crops and value chains (overlooking livestock), and further only individual points within the chain, particularly the farmers but do not go beyond to downstream actors such as aggregators, transporters, processors, distributors, retailers and consumer and upstream to input suppliers.

System approach should also be applied in creating an enabling environment, strong climate governance frameworks and government institutions are needed, to not only support capacity building and promotion of social values toward climate change awareness, adaptation mitigation and monitoring but also towards integration of social and economic factors for holistic sustainability deployment and tracking. Previous studies show that there are a number of barriers, in general, limiting small holder farmers in Kenya from integrating into agriculture value chains and adopting sustainable technologies, especially where policies and actions to address barriers still remain inadequate (Moser \& Ekstrom, 2010; Descheemaeker et al., 2016). The county government, since agriculture is now a devolved function, can create an enabling environment by removing barriers to innovation and adoption by providing knowledge and awareness to red meat value chain actors/MSMEs in order to reduce information asymmetries and help them make CSA informed decisions. Additionally, county government can mediate the economics of the decision-making process by offering subsidies for the adoption of technologies or penalize undesirable practices through regulation or charges, in a way internalizing the positive socioeconomic externalities generated by the innovation and sustaining the innovation until it is able to make for itself a compelling economic case for rapid and widespread diffusion. 
The impacts of climate change transverse across sectors and geography, greatly affecting ecosystem sustainability and food systems, therefore response initiatives, policy and actions need to be holistic, occur at multiple scales and targeting multiple sectors. This will require cross collaboration within the value chains and more so among the enabling government institutions, development partners and stakeholders. Some of the challenges identified can also be addressed through strong producers and value chain associations. There is an urgent need for a cross-sectoral coordination mechanism encompassing policy and governance frameworks, including NDCs (Nationally Determined Contributions Under), the Paris climate agreement and the growing number of climate-smart agriculture TIMPs, programmes, plans and policies, infrastructural development and social change, to work in synergy to create a favorable enabling environment for MSMEs in the livestock sector and especially in ASALs pastoralist communities who are most impacted by climate change to create climate-resilient pastoral red meat value chains. For a sectoral transformation to occur, the implementation of various policies should be expedited with emphasis on effective governance mechanisms made up of central and local governments, value chain governance and actors, aggregators' associations/cooperatives, development partners, all the way to inclusive community-based organizations. There is also a need to leverage efforts and synergies across sectors and hence develop a crosssectoral coordination mechanism to tap incentives for climate action coming from other sectors such as energy, finance and ICT, and especially leveraging the use of mobile technology to deliver CSA, policy and market information to the value chains.

\section{Conclusion}

Apart from climate change risks, agriculture sector in Kenya faces other key challenges such as scarcity of arable land, lack of access to credit, poor infrastructure, and lack of integrated markets (World Bank 2019) and the ability to effectively self-organize. These barriers can be overcome with concerted effort, creative management, change of thinking, prioritization, and related shifts in resources, land uses, and institutions (Energy Commission, 2011; Moser \& Ekstrom, 2010).

In spite of the development of CSA technologies and the positive gains arising from CSA TIMPs, wide-scale adoption of TIMPs, especially among the pastoral livestock red meat value chains, and in marginalized areas such as ASALs, remains a big challenge. KAPs (Knowledge, Attitudes, and Practices) amongst the livestock value chain actors would need to be addressed and to inform the transition to sustainable production practices in order to mitigate against negative effect on climate from keeping of large herds of livestock by farmers thereby leading to land degradation, and high methane GHG emissions, and the sustainability of the entire value chain (Grossi, et al., 2019; United Nations, 2019).

Further, there is a great opportunity to develop and strengthen the livestock red meat value chains by modernizing the value chains through the integration 
of MSMEs, utilization of modern technology, and adoption of CSA TIMPs to make them efficient, and economically, socially, and environmentally sustainable while ensuring they are optimal and profitable. All this calls for the urgent exploration and removal of barriers to the integration of MSMEs and CSA in the livestock value chains.

The overall goal of the Kenya agricultural sector is to achieve an average growth rate of $7 \%$ per year through commercialization and modernization of the sector. It aims to reduce people living below the absolute poverty lines to less than $25 \%$, to reduce food insecurity by $30 \%$, and to increase the contribution of agriculture to GDP as outlined in Vision 2030. Additionally, driven by population growth, increasing economic welfare, a growing middle class, and urbanization, the demand for meat in Kenya will continue to increase, in Nairobi alone, the demand for meat is expected to double by 2030 (Alarcon et al., 2017a). The livestock sector will grow at a faster rate (Pongiglione \& Levrini, 2014; Tasquier et al., 2014; Etwire et al., 2017) hence the phrase, "Livestock revolution" and springing from this expansion, comes the imperative to embed sustainable practices such as CSA TIMPs to not only achieve food security, mitigate effects of climate change but also to achieve sustainability of the value chain (Dietz, 2011; Chandler, 2018; Mwongera et al., 2019). This requires a strong enabling environment to strengthen MSMEs' ability to access financing, and thus the scaling of CSA TIMPs. This cannot be achieved without county and central government enabling a supportive ecosystem through inclusive regulatory policies and incentive policies such as subsidies and tax rebates. Equally the presence of enablers such as $\mathrm{CBO}$, business associations, cooperatives, civil society organizations with sustainable programs to support integration and growth of MSMEs will be critical in promoting the development of livestock value chains in ASALs and strengthening them to achieve climate resilience. However, as critical as these enablers are to the development of pastoral livestock value chains, they often have limited capacity to support them due to lack of value-added services, lack of funding and lack of access to key networks, which significantly affect their sustainability. Thus, the need to strengthen the skills and capacity to create innovative and effective change in the MSMEs and enabling institutions' attitude and organizational capacity to climate change and related risks, and mainstream adoption of sustainable business into their institutional strategies.

\section{Recommendations}

There is need to modernize the pastoral value chains that operate very traditionally, are fragmented and very underdeveloped and coupled with financial constraints these facts act as a hindrance to adoption of modern technologies that would enhance climate resilience such as CSA, to overcome such barriers it will require concerted efforts, cross-collaboration, multi-actor, multi-sectoral approach, and innovative solutions e.g. contract farming.

Contract farming can serve as a broad strategy for rural development mainly for certain high-value commodities in certain markets, and red meat would be a 
good candidate. Contract farming is one way of modernizing the pastoral livestock value chain by embedding a key actor such as a private commercial processor to compliment Kenya Meat Commission which has not been consistent in developing the livestock sector and mitigating climate risks. An ultra-modern commercial processor can accelerate value chain development by supporting, influencing and sharing relevant knowledge and technologies necessary for integration of MSMEs upstream of the chain and adoption of sustainable value chain practices such as CSA TIMPs while simultaneously addressing market failures by integrating smallholders into modern agricultural livestock value chains and mainstreaming food safety measures. The contractor will enable the chains by providing them with inputs, technical assistance, and market access. Contract livestock production can be an effective approach for helping smallholder livestock farmers raise productivity and access more remunerative red meat markets regionally and globally. However, there is a need to solve for the imbalance of power, in the value chain governance, between farmers and the processing companies that organize and manage contract-farming schemes which may put small farmers especially pastoralists at a distinct disadvantage due to information asymmetry and economic imbalance. On the other hand, the processing companies may be hesitant to enter into such an arrangement with pastoralists due to climate risks and the risk of their moving from place to place creating unpredictability of constant supply of livestock to the processing companies, hence the need for eventual plans for transitioning pastoralist to intensive production that limit nomadism, especially in the face of shrinking available pastoral land while conserving the environment.

\section{Further Research}

So, while climate-smart interventions exist, there is a lack of context based technologies, innovation and practices geared towards pastoral communities in ASALs and only limited evidence of the overall progress in uptake of CSA since its launch in 2010, Hague conference. The current status of CSA adaptation and effectiveness nationally and locally is difficult to determine, let alone in marginalized areas such as ASALs and Livestock sector that have largely been overlooked. Adaptation monitoring and evaluation ( $\mathrm{M} \& \mathrm{E}$ ) is increasingly being seen as a vital component in the process of adapting to climate change; serving to increase the understanding of climate risks, increase the effectiveness of adaptation approaches and eventual accountability under the United Nations Framework Convention on Climate Change and hence the need for further research on CSA contextualization, uptake, scaling, adaptation and monitoring frameworks and tools in the ASALs livestock sector, where pastoralism accounts for $86 \%$ of Kenya red meat value chain.

\section{Authors' Contributions}

Ms. Mary Waceke Muia: Research design, data collection and manuscript prepa- 
ration.

Dr. Bessy Kathambi: Manuscript review.

Prof. Henry Mutembei: Manuscript supervision.

Prof. John Mburu: Manuscript supervision.

\section{Acknowledgements}

I would like to acknowledge the support of my family, the KCSAP (Kenya Climate Smart Agriculture Project) and my supervisors without whom this research would not have been possible.

\section{Conflicts of Interest}

The authors declare no conflict of interest.

\section{References}

Abegunde, V. O., Sibanda, M., \& Obi, A. (2020). Determinants of the Adoption of Climate-Smart Agricultural Practices by Small-Scale Farming Households in King Cetshwayo District Municipality, South Africa. Sustainability (Switzerland), 12, 195. https://doi.org/10.3390/su12010195

Aggarwal, P. K., Jarvis, A., Campbell, B. M., Zougmoré, R. B., Khatri-Chhetri, A., Vermeulen, S. J., Tan Yen, B. et al. (2018). The Climate-Smart Village Approach: Framework of an Integrative Strategy for Scaling Up Adaptation Options in Agriculture. Ecology and Society, 23, 14. https://doi.org/10.5751/ES-09844-230114

Alarcon, P., Dominguez-Salas, P., Häsler, B., Rushton, J., Alarcon, P., Fèvre, E. M., Ahmed, S. et al. (2017a). Mapping of Beef, Sheep and Goat Food Systems in Nairobi-A Framework for Policy Making and the Identification of Structural Vulnerabilities and Deficiencies. Agricultural Systems, 152, 1-17. https://doi.org/10.1016/j.agsy.2016.12.005

Alarcon, P., Fèvre, E. M., Muinde, P., Murungi, M. K., Kiambi, S., Akoko, J., \& Rushton, J. (2017). Urban Livestock Keeping in the City of Nairobi: Diversity of Production Systems, Supply Chains, and Their Disease Management and Risks. Frontiers in Veterinary Science, 4, 171. https://doi.org/10.3389/fvets.2017.00171

Ali, D. A., Deininger, K., \& Goldstein, M. (2014). Environmental and Gender Impacts of Land Tenure Regularization in Africa: Pilot Evidence from Rwanda. Journal of Development Economics, 110, 262-275. https://doi.org/10.1016/j.jdeveco.2013.12.009

Atela, J., Gannon, K. E., \& Crick, F. (2018). Climate Change Adaptation among Female-Led Micro, Small and Medium Enterprises in Semi-Arid Areas: A Case Study from Kenya. https://doi.org/10.1007/978-3-319-71025-9_97-1

Baker, E. (2005). Institutional Barriers to Technology Diffusion in Rural Africa. 2005 Annual Meeting, Providence, 24-27 July 2005, 1-30.

Barro, R. J., \& Sala-I-Martin, X. (1992). Convergence. Journal of Political Economy, 100, 223-251. https://doi.org/10.1086/261816

Bergevoet, R., \& Van Engelen, A. (2014). The Kenyan Meat Sector; Opportunities for Dutch Agribusiness. Report No. 2014-032, LEI Wageningen UR. https://edepot.wur.nl/370228

Birch, I. (2018). Agricultural Productivity in Kenya: Barriers and Opportunities. https://opendocs.ids.ac.uk/opendocs/handle/20.500.12413/14211

Chandler, C. I. R. (2018). Knowledge, Attitudes, and Practice Surveys. In The International Encyclopedia of Anthropology (pp. 1-2). Wiley. 
https://doi.org/10.1002/9781118924396.wbiea1387

Cullen, K. L., Edwards, B. D., Casper, W. C., \& Gue, K. R. (2014). Employees’ Adaptability and Perceptions of Change-Related Uncertainty: Implications for Perceived Organizational Support, Job Satisfaction, and Performance. Journal of Business and Psychology, 29, 269-280. https://doi.org/10.1007/s10869-013-9312-y

Dai, Z., Weisenstein, D. K., \& Keith, D. W. (2018). Tailoring Meridional and Seasonal Radiative Forcing by Sulfate Aerosol Solar Geoengineering. Geophysical Research Letters, 45, 1030-1039. https://doi.org/10.1002/2017GL076472

Dearing, J. W. (2009). Applying Diffusion of Innovation Theory to Intervention Development. Research on Social Work Practice, 19, 503-518. https://doi.org/10.1177/1049731509335569

Dearing, J. W., \& Cox, J. G. (2018). Diffusion of Innovations Theory, Principles, and Practice. Health Affairs, 37, 183-190. https://doi.org/10.1377/hlthaff.2017.1104

Descheemaeker, K., Oosting, S. J., Homann-Kee Tui, S., Masikati, P., Falconnier, G. N., \& Giller, K. E. (2016). Climate Change Adaptation and Mitigation in Smallholder CropLivestock Systems in Sub-Saharan Africa: A Call for Integrated Impact Assessments. Regional Environmental Change, 16, 2331-2343. https://doi.org/10.1007/s10113-016-0957-8

Devaux, A., Torero, M., Donovan, J., \& Horton, D. (2018). Agricultural Innovation and Inclusive Value-Chain Development: A Review. Journal of Agribusiness in Developing and Emerging Economies, 8, 99-123. https://doi.org/10.1108/JADEE-06-2017-0065

Dietz, M. (2011). Value Chain Governance that Benefits the Poor (pp. 1-15).

Energy Commission, C. (2011). Barriers to Climate Change Adaptation: A Diagnostic Framework.

Ericsson, E., \& Lindberg, A. (2018). Development Opportunities in the Land Management Process in Rwanda.

Etwire, P. M., Buah, S., Ouédraogo, M., Zougmoré, R., Partey, S. T., Martey, E., Bayala, J., \& Dayamba, S. D. (2017). An Assessment of Mobile Phone-Based Dissemination of Weather and Market Information in the Upper West Region of Ghana. Agriculture and Food Security, 6, 1-9. https://doi.org/10.1186/s40066-016-0088-y

Faber, A., \& Hoppe, T. (2013). Co-Constructing a Sustainable Built Environment in the Netherlands-Dynamics and Opportunities in an Environmental Sectoral Innovation System. Energy Policy, 52, 628-638. https://doi.org/10.1016/j.enpol.2012.10.022

Fang, L. (2009). Entry Barriers, Competition, and Technology Adoption. https://doi.org/10.2139/ssrn.1433128

FAO (2003). Value Chain Analysis: A Case Study of Mangoes in Kenya (p. 11). Sugar and Beverages Group Raw Materials, Tropical and Horticultural Products Service Commodities and Trade Division Food and Agriculture Organization of the United Nations.

Fielding, K. S., \& Hornsey, M. J. (2016). A Social Identity Analysis of Climate Change and Environmental Attitudes and Behaviors: Insights and Opportunities. Frontiers in Psychology, 7, Article No. 121. https://doi.org/10.3389/fpsyg.2016.00121

Gledhill, R., \& Herweijer, C. (2012). Challenges and Opportunities for Scaling-Up Investment in CSA Prepared by PwC with Support from 22 Authors.

Godde, C. M., Mason-D’Croz, D., Mayberry, D. E., Thornton, P. K., \& Herrero, M. (2021). Impacts of Climate Change on the Livestock Food Supply Chain: A Review of the Evidence. Global Food Security, 28, Article No. 100488.

https://doi.org/10.1016/j.gfs.2020.100488

Gonzalez, C. (2005). Task Workload and Cognitive Abilities in Dynamic Decision Mak- 
ing. Human Factors, 47, 92-101. https://doi.org/10.1518/0018720053653767

Grossi, G., Goglio, P., Vitali, A., \& Williams, A. G. (2019). Livestock and Climate Change: Impact of Livestock on Climate and Mitigation Strategies. Animal Frontiers, 9, 69-76. https://doi.org/10.1093/af/vfy034

Ishtiaq, M. (2019). Book Review Creswell, J. W. (2014). Research Design: Qualitative, Quantitative and Mixed Methods Approaches (4th Ed.). Thousand Oaks, CA: Sage. English Language Teaching, 12, 40-41. https://doi.org/10.5539/elt.v12n5p40

Jordaan, H., Grové, B., \& Backeberg, G. R. (2014). Conceptual Framework for Value Chain Analysis for Poverty Alleviation among Smallholder Farmers. Agrekon, 53, 1-25. https://doi.org/10.1080/03031853.2014.887903

Khalifa, M., \& Ning Shen, K. (2008). Explaining the Adoption of Transactional B2C Mobile Commerce. Journal of Enterprise Information Management, 21, 110-124. https://doi.org/10.1108/17410390810851372

Khatri-Chhetri, A., Pant, A., Aggarwal, P. K., Vasireddy, V. V., \& Yadav, A. (2019). Stakeholders Prioritization of Climate-Smart Agriculture Interventions: Evaluation of a Framework. Agricultural Systems, 174, 23-31. https://doi.org/10.1016/j.agsy.2019.03.002

Kim, Y., \& Crowston, K. (2011). Technology Adoption and Use Theory Review for Studying Scientists' Continued Use of Cyber-Infrastructure. Proceedings of the American Society for Information Science and Technology, 48, 1-10. https://doi.org/10.1002/meet.2011.14504801197

Linnér, B. O., \& Wibeck, V. (2020). Conceptualising Variations in Societal Transformations towards Sustainability. Environmental Science and Policy, 106, 221-227. https://doi.org/10.1016/j.envsci.2020.01.007

Maina, J., Wandiga, S., Gyampoh, B., \& Charles, K. K. G. (2020). Assessment of Land Use and Land Cover Change Using GIS and Remote Sensing: A Case Study of Kieni, Central Kenya. Journal of Remote Sensing \& GIS, 9, 1-5.

https://www.longdom.org/open-access/assessment-of-land-use-and-land-cover-change -using-gis-and-remote-sensing-a-case-study-of-kieni-central-kenya-52802.html

Matsui, H., Hori, K., Yamada, E., \& Kodama, K. (2020). Visualization and Punctuation of Psychological Counseling by Qualitative and Quantitative Methods. Psychology, 11, 796-821. https://doi.org/10.4236/psych.2020.115053

Ministry of Agriculture, Livestock Fisheries Irrigation (2018). Agricultural Sector Transformation and Growth Strategy: Towards Sustainable Agricultural Transformation and Food Security in Kenya (p. 46).

Moser, S. C., \& Ekstrom, J. A. (2010). A Framework to Diagnose Barriers to Climate Change Adaptation. Proceedings of the National Academy of Sciences of the United States of America, 107, 22026-22031. https://doi.org/10.1073/pnas.1007887107

Mukanyandwi, V., Kurban, A., Hakorimana, E., Nahayo, L., Habiyaremye, G., Gasirabo, A., \& Sindikubwabo, T. (2019). Seasonal Assessment of Drinking Water Sources in Rwanda Using GIS, Contamination Degree (Cd), and Metal Index (MI). Environmental Monitoring and Assessment, 191, 1-13. https://doi.org/10.1007/s10661-019-7757-9

Mukherjee, A., \& Sarkar, S. (2018). Institutional Barriers to Technology Adoption: The Case of Silk Technology in Colonial India. SSRN Electronic Journal.

Mutisya, S. M., \& Barker, M. (2011). Pupils' Environmental Awareness and Knowledge: A Springboard for Action in Primary Schools in Kenya's Rift Valley. Science Education International, 22, 55-71.

Mwongera, C., Nowak, A., Notenbaert, A. M. O., Grey, S., Osiemo, J., Kinyua, I., Girvetz, 
E. et al. (2019). Climate-Smart Agricultural Value Chains: Risks and Perspectives. In T. Rosenstock, A. Nowak, \& E. Girvetz (Eds.), The Climate-Smart Agriculture Papers (pp. 235-245). Springer International Publishing. https://doi.org/10.1007/978-3-319-92798-5_20

Nkonya, E., Mirzabaev, A., \& Von Braun, J. (2015). Economics of land degradation and improvement: An introduction and overview. In E. Nkonya, A. Mirzabaev, \& J. von Braun (Eds.), Economics of Land Degradation and Improvement-A Global Assessment for Sustainable Development (pp. 1-14). Springer International Publishing. https://doi.org/10.1007/978-3-319-19168-3_1

Otieno, D. J., Hubbard, L., \& Ruto, E. (2012). Determinants of Technical Efficiency in Beef Cattle Production in Kenya: Application of the Tobit Method. http://erepository.uonbi.ac.ke/handle/11295/31665

Pantano, E., \& Di Pietro, L. (2012). Understanding Consumer's Acceptance of Technology-Based Innovations in Retailing. Journal of Technology Management \& Innovation, 7, 1-19. https://doi.org/10.4067/S0718-27242012000400001

Raciti, S. M., Groffman, P. M., Jenkins, J. C., Pouyat, R. V., Fahey, T. J., Pickett, S. T. A., \& Cadenasso, M. L. (2011). Accumulation of Carbon and Nitrogen in Residential Soils with Different Land-Use Histories. Ecosystems, 14, 287-297. https://doi.org/10.1007/s10021-010-9409-3

Said, M. Y., Ogutu, J. O., Kifugo, S. C., Makui, O., Reid, R. S., \& de Leeuw, J. (2016). Effects of Extreme Land Fragmentation on Wildlife and Livestock Population Abundance and Distribution. Journal for Nature Conservation, 34, 151-164. https://doi.org/10.1016/j.jnc.2016.10.005

Scott, R. (2004). Institutional Theory: Contributing to a Theoretical Research Program. In K. G. Smith, \& M. A. Hitt (Eds.), Great Minds in Management: The Process of Theory Development (pp. 460-484). Oxford: Oxford University Press.

Scott, S., \& Mcguire, J. (2017). Using Diffusion of Innovation Theory to Promote Universally Designed College Instruction. International Journal of Teaching, 29, 119-128.

Smith, R. A., Kim, Y., Zhu, X., Doudou, D. T., Sternberg, E. D., \& Thomas, M. B. (2018). Integrating Models of Diffusion and Behavior to Predict Innovation Adoption, Maintenance, and Social Diffusion. Journal of Health Communication, 23, 264-271. https://doi.org/10.1080/10810730.2018.1434259

Sourcebook, S. (2013). Climate Smart Agriculture.

Stein, C., \& Barron, J. (2017). Mapping Actors along Value Chains: Integrating Visual Network Research and Participatory Statistics into Value Chain Analysis. Colombo: International Water Management Institute (IWMI). https://doi.org/10.5337/2017.216

Tankha, S., Fernandes, D., \& Narayanan, N. C. (2020). Overcoming Barriers to Climate Smart Agriculture in India. International Journal of Climate Change Strategies and Management, 12, 108-127. https://doi.org/10.1108/IJCCSM-10-2018-0072

Tasquier, G., Pongiglione, F., \& Levrini, O. (2014). Climate Change: An Educational Proposal Integrating the Physical and Social Sciences. Procedia-Social and Behavioral Sciences, 116, 820-825. https://doi.org/10.1016/j.sbspro.2014.01.304

Thorlakson, T., \& Neufeldt, H. (2012). Reducing Subsistence Farmers' Vulnerability to Climate Change: Evaluating the Potential Contributions of Agroforestry in Western Kenya. Agriculture and Food Security, 1, Article No. 15. https://doi.org/10.1186/2048-7010-1-15

Thornton, P., Enahoro, D., Njiru, N., Wijk, M. van, Ashley, L., Cramer, L., Ericksen, P., \& Graham, M. (2019). Program for Climate-Smart Livestock Systems. Country Stocktake: Ethiopia. https://cgspace.cgiar.org/handle/10568/106291 
Torquebiau, E., Rosenzweig, C., Chatrchyan, A. M., Andrieu, N., \& Khosla, R. (2018). Identifying Climate-Smart Agriculture Research Needs. Cahiers Agricultures, 27, 26001. https://doi.org/10.1051/cagri/2018010

UNEP (2010). Assessing Global Land Use: Balancing Consumption with Sustainable Supply.

United Nations (2019) Report of the Secretary-General On the 2019 Climate Action Summit the Way Forward in 2020.

https://www.un.org/sites/un2.un.org/files/cas_report_11_dec_0.pdf

Vermeulen, S. J., Campbell, B. M., \& Ingram, J. S. I. (2012). Climate Change and Food Systems. Annual Review of Environment and Resources, 37, 195-222. https://doi.org/10.1146/annurev-environ-020411-130608

Williamson, I., Enemark, S., Wallace, J., Rajabifard, A., Enemark, W., Rajabifard, W., \& Press, E. (2010). Land Administration for Sustainable Development.

World Bank. (2019). Annual Report 2019: Ending Poverty, Investing in Opportunity. World Bank Group, 319.

https://documents.worldbank.org/en/publication/documents-reports/documentdetail/ 156691570147766895/the-world-bank-annual-report-2019-ending-poverty-investing-i n-opportunity

Zhang, X., Yu, P., Yan, J., Ton, A. M., \& Spil, I. (2015). Using Diffusion of Innovation Theory to Understand the Factors Impacting Patient Acceptance and Use of Consumer E-Health Innovations: A Case Study in a Primary Care Clinic Healthcare Needs and Demand. BMC Health Services Research, 15, 71.

https://doi.org/10.1186/s12913-015-0726-2 